\title{
Promoter hypermethylation of the 14-3-3 o, SYK and CAGE-1 genes is related to the various phenotypes of urinary bladder carcinomas and associated with progression of transitional cell carcinomas
}

\author{
EKKEHARD KUNZE ${ }^{1}$, MAIKE WENDT ${ }^{1}$ and THILO SCHLOTT $^{2}$ \\ Departments of ${ }^{1}$ Osteopathology and Haematopathology, ${ }^{2}$ Pathology, \\ Georg-August-University, Göttingen, Germany
}

Received March 21, 2006; Accepted May 19, 2006

\begin{abstract}
To explore the significance of epigenetic mechanisms in urinary bladder carcinogenesis mediated by methylation of cytosine in $\mathrm{CpG}$ dinucleotides at $5^{\prime}$ promoter regions, we analysed the methylation status of a broad panel of different genes in transitional cell carcinomas (TCC) and nonurothelial cancers, among which the 14-3-3 o, SYK and CAGE-1 genes were recognised as promising target genes. Using methylation-specific PCR, the rate of DNA hypermethylation proved to be related to the various histopathological cancer subtypes. The higher frequency of promoter methylation of the 14-3-3 $\sigma(57.1 \%)$ and SYK (64.3\%) genes in high-grade, high-stage TCC in association with a reduced or even lacking immunohistochemical protein expression than in low-grade, low-stage TCC (28.6\% and $42.9 \%$, respectively), indicates that aberrant methylation of these genes plays an essential role in the progression of TCC. The importance of DNA hypermethylation in the conversion of TCC from a low to a high malignant potential was strongly supported by the finding that, unlike superficial low-grade TCC, advanced muscle invasive TCC showed a concurrent promoter methylation of the 14-3-3 $\sigma$, SYK and CAGE-1 genes. Squamous cell carcinomas revealed a peak incidence of hypermethylation of the 14-3-3 $\sigma$ gene (80\%), and conversely, the lowest methylation frequency of the SYK gene $(13.3 \%)$. Undifferentiated small cell carcinomas disclosed a promoter methylation of the 14-3-3 $\sigma$, SYK and CAGE-1 genes in only a quarter each for the cases. Although a
\end{abstract}

Correspondence to: Dr E. Kunze, Center of Pathology, University of Göttingen, D-37099 Göttingen, Germany

E-mail: ekunze@med.uni-goettingen.de

Key words: urinary bladder, transitional cell carcinomas, squamous cell carcinomas, undifferentiated small cell cancers, promoter methylation, 14-3-3 o, SYK, CAGE-1, PTEN, COX-2, RUNX-3, HIC-1, immunohistochemistry correlation between the methylation status and gene activity in squamous cell and undifferentiated small cell carcinomas was not observed, the underexpression of the SYK protein products in both cancer types and additionally of the 14-3-3 $\sigma$ protein in small cell carcinomas appeared to be related to the aggressive clinical behaviour of both these nonurothelial bladder carcinomas. The relevance of the high frequency of DNA hypermethylation of the CAGE-1 antigen in TCC and squamous cell carcinomas merits further study, particularly in relation to anticancer immunotherapy. The methylation status of the PTEN, COX-2, RUNX-3 and HIC-1 genes was found to be unaltered. In conclusion, the different patterns of aberrant methylation of the 14-3-3 o, SYK and CAGE-1 genes in the various histopathological cancer types of the urinary bladder point to a role in tumor cell differentiation, resulting in the phenotypical conversion of TCC into nonurothelial carcinomas and in the progression of TCC to a more malignant potential.

\section{Introduction}

There is a growing body of evidence that gene inactivation particularly of tumor suppressors plays a crucial role in the modification, progression and metastasis of tumorigenesis, including urinary bladder carcinogenesis (reviewed in refs. 1-4). Functional gene repression can be caused by classic genetic alterations or, alternatively, by epigenetic mechanisms mediated by methylation of normally unmethylated cytosine in $\mathrm{CpG}$ dinucleotides at the $5^{\prime}$ promoter region, leading to transcriptional silencing (reviewed in refs. 5-8). The question we addressed in the present study was whether DNA hypermethylation is involved in urinary bladder carcinogenesis, particularly in tumor progression and the formation of nonurothelial carcinomas, characterised by a poor prognosis. Our previous morphological and immunohistochemical studies provided evidence that nonurothelial carcinomas (squamous cell carcinomas, adenocarcinomas and undifferentiated small cell carcinomas) originate histogenetically either primarily from corresponding metaplasias of the normal transitional cell epithelium or, more frequently, secondarily from pre-existent TCC by a metaplastic process (squamous cell carcinomas and adenocarcinomas) or via a dedifferentiation 
(undifferentiated small cell cancers) of the initially urothelial differentiated tumor cells (9-12). In a previous moleculargenetic investigation we were able to document a high frequency of promoter methylation of the caveolin- 1 gene in undifferentiated small cell carcinomas as well as in squamous cell carcinomas, whereas TCC were not hypermethylated at all (13). Moreover, aberrant DNA methylation of the hDAB2IP gene occurred more frequently in advanced muscle invasive high-grade than in superficial low-grade TCC. To gain further insight into the significance of epigenetic events in urinary bladder carcinogenesis, we analysed the methylation status of a large panel of different genes, yielding promoter hypermethylation of the 14-3-3 $\sigma$, SYK and CAGE-1 genes to play a role in progression of transitional cell carcinomas from a low to a high malignant potential and in the development of the various phenotypical cancer types.

\section{Materials and methods}

Specimens. In this study we analysed archival, formalin-fixed and paraffin-embedded samples of urinary bladder cancers, consisting of 14 noninvasive superficial low-grade (grade 1), low-stage (pTa) papillary and 14 muscle invasive nonpapillary (solid) high-grade (grade 3 ), high-stage (pT2b) TCC. Additionally, 15 muscle invasive squamous cell carcinomas (grades 2 and 3) with or without keratinisation and 12 muscle invasive undifferentiated small cell carcinomas were included in the study. The tumor samples were obtained from patients who had undergone transurethral resection or radical cystectomy. Six probes of normal, nonneoplastic bladder mucosa from cystectomy specimens of different patients served as controls.

Molecular-genetic assays. For molecular-genetic analysis, histological sections of $5 \mu \mathrm{m}$ in thickness were prepared from the paraffin-embedded samples. Following identification of the cancer tissue and histopathological diagnosis of the tumor type in a section stained with hematoxylin and eosin, consecutive unstained sections were used to separate the tumor material from nonneoplastic tissues and mechanically scraped from the slides using a sharp knife.

DNA extraction and $\beta$-globin PCR. DNA was extracted from the cancer tissues with the QIAamp DNA minikit (Qiagen, Hilden, Germany) according to the manufacturer's instructions. The DNA diluted in $500 \mathrm{ml}$ bidistilled water was mixed with $500 \mu 1$ isopropanol and incubated for $60 \mathrm{~min}$ at room temperature. The precipitated DNA was collected by centrifuging the solution for $60 \mathrm{~min}$ at $14,000 \mathrm{x} \mathrm{g}$ (Heraeus Biofuge 15, Osterode/Harz, Germany) and washed with $100 \mu 1$ ethanol (96\%). The tubes were incubated without lids at room temperature for $10 \mathrm{~min}$. Thereafter, the DNA pellets were dissolved in $10 \mu \mathrm{l}$ bidistilled water at $50^{\circ} \mathrm{C}$ for $10 \mathrm{~min}$. A quantity of $0.5 \mu 1 \mathrm{DNA}$ was diluted 1:100 in bidistilled water and used for $\beta$-globin PCR. Primers were sense 5'-CTT CTG ACA CAA CTG TGT TCA CT-3' and anti-sense 5'-TCA CCA CCA ACT TCA TCC ACG T-3' (product size 123 bp). PCR was performed at a total volume of $50 \mu 1$ in a Primus-25 DNA thermocycler (MWG, Ebersberg, Germany). Each reaction mixture contained $200 \mathrm{ng}$ DNA, $10 \mathrm{pmol}$ of each sense and antisense primer, $4 \mu 1 \mathrm{dNTPs}$ (10 mM each), $5 \mu 1$ of $10 \times$ reaction buffer buffer [Tris-HCI ( $\mathrm{pH} \mathrm{8.7),} \mathrm{KCl}$, (NH4) ${ }_{2} \mathrm{SO}_{4}, 15 \mathrm{mM} \mathrm{MgCI}$ ], and 1 unit HotStarTaq polymerase (Qiagen). The thermal cycling conditions consisted of an initial 15 min step at $95^{\circ} \mathrm{C}$ to denaturate the DNA and to activate the HotStarTaq DNA polymerase. The DNA obtained was amplified by applying 40 cycles $\left(95^{\circ} \mathrm{C}\right.$ for $30 \mathrm{sec}$, $55^{\circ} \mathrm{C}$ for $60 \mathrm{sec}, 72^{\circ} \mathrm{C}$ for $60 \mathrm{sec}$ ). The cycling protocol was completed with a $7 \mathrm{~min}$ step at $72^{\circ} \mathrm{C}$ to prevent incomplete synthesis of PCR products. The PCR fragments obtained were separated on a $3 \%$ agarose gel stained with ethidium bromide (5 $\mu 1 / 40 \mathrm{ml}$ agarose).

Methylation-specific PCR. DNA isolated from tumor samples $(1 \mu \mathrm{g})$ was treated with sodium bisulfite using the CpGenome DNA modification kit (Intergen Company, Oxford, UK) according to the manufacturer's instructions. Modified DNA ( $2 \mu 1,1 / 5$ volume) was used for PCR amplification. The primers for analysing the different genes were the following. 14-3-3 $\sigma$ [primers were those applied by Ferguson et al (14)]: for methylated sequences, sense 5'-TGG TAG TTT TTA TGA AAG GCG TC-3' and antisense 5'-CCT CTA ACC GCC CAC CAC G-3' (product size $105 \mathrm{bp}$ ); for unmethylated sequences, sense 5'-ATG GTA GTT TTT ATG AAA GGT GTT-3' and antisense 5'-CCC TCT AAC CAC CCA CCA CA-3' (product size $107 \mathrm{bp}$ ). SYK [primers were those described by Wand et al (15)]: for methylated sequences, sense 5'-CGA TTT CGC GGG TTT CGT TC-3' and antisense 5'-AAA ACG AAC GCA ACG CGA AAC-3' (product size $140 \mathrm{bp}$ ); for unmethylated sequences, sense 5'-ATT TTG TGG GTT TTG TTT GGT G-3' and antisense 5'-ACT TCC TTA ACA CAC CCA AAC-3' (product size 243 bp). CAGE-1 (16): for methylated sequences, sense 5'-TTT TAT ACG ATT CGG AAT TCG AC-3' and antisense 5'-CAA ATC TAC GAC CTA TTT CCC G-3' (product size $150 \mathrm{bp}$ ); for unmethylated sequences, sense 5'-GTT TTT TAT ATG ATT TGG AAT TTG AT-3' and antisense 5'-AAT TCA AAT CTA CAA CCT ATT TCC CA (product size $150 \mathrm{bp}$ ). PTEN (17): for methylated sequences, sense 5'-TTC GTT CGT CGT CGT CGT ATT T-3' and antisense 5'-GCC GCT TAA CTC TAA ACC GCA ACC G-3' (product size 206 bp); for unmethylated sequences, sense 5'-GTG TTG GTG GAG GTA GTT GTT T-3' and antisense 5'-ACC ACT TAA CTC TAA ACC ACA ACC A-3' (product size 162 bp). COX-2 (18): for methylation sequences, sense 5'-TTA GAT ACG GCG GCG GCG GC-3' and antisense 5'-TCT TTA CCC GAA CGC TTC CG-3' (product size $161 \mathrm{bp}$ ); for unmethylated sequences, sense 5'-ATA GAT TAG ATA TGG TGG TGG TGG T-3' and antisense 5'-CAC AAT CTT TAC CCA AAC ACT TCC A-3' (product size $171 \mathrm{bp}$ ). RUNX-3 (19): for methylated sequences, sense 5'-TTA CGA GGG GCG CTG GTA CGC GGG-3' and antisense 5'-AAA ACG ACC GAC GCG AAC GCC TCC-3' (product size 149 bp); for unmethylated sequences, sense 5'-TTA TGA GGG GTG GTT GTA TGT GGG-3' and antisense 5'-AAA ACA ACC AAC ACA AAC ACC TCC-3' (product size 149 bp). HIC-1 (20): for methylated sequences, sense 5'-TTC GTT TTT CGC GCG GTC GTC GTT C-3' and antisense 5'-CGA AAA ACC AAC GCC TCC CGC CTC G-3' (product size 249 bp); for unmethylated sequences, sense 5'-TTT GTT TTT TGT GTG GTT GTT GTT T-3' and antisense 5'-CAA AAA ACC AAC ACC TCC CAC CTC A-3' (product size 278 bp). 
Table I. Methylation at the promoter region of the genes analysed in low-grade (grade 1), low-stage (pTa) papillary TCC of the urinary bladder (+ promoter methylation present, - promoter methylation absent).

\begin{tabular}{lccccccc}
\hline \multirow{2}{*}{ No. of case } & \multicolumn{7}{c}{ Methylation status } \\
\cline { 2 - 7 } 1 & $14-3-3 \sigma$ & SYK & CAGE-1 & PTEN & COX-2 & RUNX-3 & HIC-1 \\
2 & - & + & + & + & + & - & - \\
3 & - & - & + & - & - & - & - \\
4 & - & + & + & - & - & - & - \\
5 & - & - & - & - & - & - & - \\
6 & - & + & - & - & - & - & - \\
7 & - & - & + & - & - & - & - \\
8 & - & - & + & - & - & - & - \\
9 & + & - & - & - & - & - & - \\
10 & - & - & - & - & - & - & - \\
11 & + & + & + & - & - & - & - \\
12 & + & + & - & - & - & - & - \\
13 & - & + & + & - & - & - & - \\
14 & $14 / 4$ & $14 / 6$ & $14 / 9$ & $14 / 1$ & $14 / 1$ & $14 / 0$ & $14 / 0$ \\
\hline Incidence & $(28 \%)$ & $(42.9 \%)$ & $(64.3 \%)$ & $(7.1 \%)$ & $(7.1 \%)$ & $(0 \%)$ & $(0 \%)$ \\
& & - & - & - & - & - \\
\hline
\end{tabular}

Table II. Methylation at the promoter region of the genes analysed in high-grade (grade 3), high-stage (pT2b) nonpapillary (solid) TCC of the urinary bladder (+ promoter methylation present, - promoter methylation absent).

\begin{tabular}{lccccccc}
\hline \multirow{2}{*}{ No. of case } & \multicolumn{7}{c}{ Methylation status } \\
\cline { 2 - 7 } 1 & $14-3-3 \sigma$ & SYK & CAGE-1 & PTEN & COX-2 & RUNX-3 & HIC-1 \\
2 & + & + & + & - & - & - & - \\
3 & + & + & + & - & - & - & - \\
4 & - & - & - & - & - & - & - \\
5 & + & + & + & - & - & - & - \\
6 & - & - & - & - & - & - & - \\
7 & + & + & + & - & - & - & - \\
8 & - & - & - & - & - & - & - \\
9 & + & + & + & - & - & - & - \\
10 & + & + & - & - & - & - & - \\
11 & + & + & + & - & - & - & - \\
12 & - & - & - & - & - & - & - \\
13 & + & + & + & - & - & - & - \\
14 & $14 / 8$ & $14 / 9$ & $14 / 9$ & $14 / 0$ & $14 / 0$ & $14 / 1$ & $14 / 0$ \\
\hline Incidence & $(57.1 \%)$ & $(64.3 \%)$ & $(64.3 \%)$ & $(0 \%)$ & $(0 \%)$ & $(7.1 \%)$ & $(0 \%)$ \\
& & & + & + & - & - & - \\
\hline
\end{tabular}

PCR was performed at a total volume of $50 \mu 1$ using a Primus-25 thermocycler. Each reaction mixture contained $200 \mathrm{ng}$ template, $20 \mathrm{pmol}$ of each sense and antisense primer, $4 \mu \mathrm{d}$ dNTPs (200 mM each), $5 \mu 110 \mathrm{x}$ reaction buffer buffer [Tris-HCI (pH 8.7), KCI, (NH4) ${ }_{2} \mathrm{SO}_{4}, 15 \mathrm{mM} \mathrm{MgCI} 2$ ], and
1 unit HotStarTaq DNA polymerase (Qiagen). The thermocycling conditions consisted of an initial $15 \mathrm{~min}$ step at $95^{\circ} \mathrm{C}$ to denaturate the DNA and to activate the HotStarTaq DNA polymerase. Further amplification conditions for the various methylated and unmethylated genes were as follows. PTEN: 
Table III. Methylation at the promoter region of the genes analysed in squamous cell carcinomas of the urinary bladder (+ promoter methylation present, - promoter methylation absent).

\begin{tabular}{lccccccc}
\hline \multirow{2}{*}{ No. of case } & \multicolumn{7}{c}{ Methylation status } \\
\cline { 2 - 7 } 1 & $14-3-3 \sigma$ & SYK & CAGE-1 & PTEN & COX-2 & RUNX-3 & HIC-1 \\
2 & + & - & + & - & - & - & - \\
3 & + & - & + & - & - & - & - \\
4 & + & - & + & - & - & - & - \\
5 & + & - & + & - & - & - & - \\
6 & + & - & + & - & - & - & - \\
7 & - & - & - & - & - & - & - \\
8 & - & - & - & - & - & - & - \\
9 & + & - & - & - & - & - & - \\
10 & + & - & - & - & - & - & - \\
11 & + & - & - & - & + & - & - \\
12 & - & - & + & - & - & - & - \\
13 & + & + & - & - & - & - & - \\
14 & + & - & - & - & - & - & - \\
15 & + & $15 / 2$ & $15 / 8$ & $15 / 0$ & $15 / 1$ & $15 / 1$ & - \\
\hline Incidence & $15 / 12$ & $(13.3 \%)$ & $(53.3 \%)$ & $(0 \%)$ & $(6.7 \%)$ & $(6.7 \%)$ & $(0 \%)$ \\
& $(80 \%)$ & & - & - & - & - & - \\
\hline
\end{tabular}

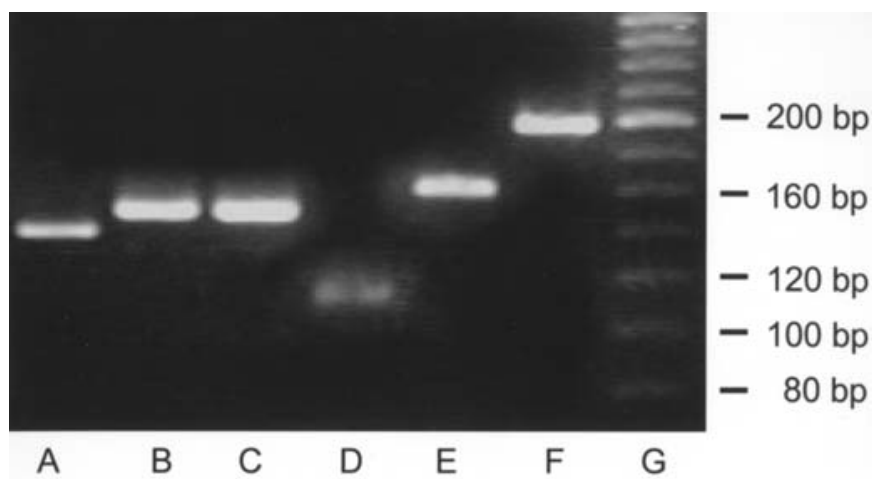

Figure 1. Methylation-specific PCR analysis of carcinomas of the urinary bladder, demonstrating hypermethylated promoter sequences of the various genes studied, separated by electrophoresis on agarose gel $(3 \%)$ and stained with ethidium bromide. Lane A, SYK; lane B, CAGE-1; lane C, RUNX-3; lane D, 14-3-3 o; lane E, COX-2; lane F, PTEN; lane G, molecular weight standard.

45 cycles $\left(94^{\circ} \mathrm{C}\right.$ for $45 \mathrm{sec}, 61^{\circ} \mathrm{C}$ for $30 \mathrm{sec}, 72^{\circ} \mathrm{C}$ for $\left.30 \mathrm{sec}\right)$; COX-2: 45 cycles $\left(95^{\circ} \mathrm{C}\right.$ for $30 \mathrm{sec}, 52^{\circ} \mathrm{C}$ for $45 \mathrm{sec}, 72^{\circ} \mathrm{C}$ for $60 \mathrm{sec})$; $14-3-3 \sigma: 45$ cycles $\left(95^{\circ} \mathrm{C}\right.$ for $45 \mathrm{sec}, 56^{\circ} \mathrm{C}$ for $30 \mathrm{sec}$, $72^{\circ} \mathrm{C}$ for $\left.30 \mathrm{sec}\right)$; SYK: 45 cycles $\left(94^{\circ} \mathrm{C}\right.$ for $45 \mathrm{sec}, 60^{\circ} \mathrm{C}$ for $45 \mathrm{sec}, 72^{\circ} \mathrm{C}$ for $\left.60 \mathrm{sec}\right)$; RUNX-3: 45 cycles $\left(94^{\circ} \mathrm{C}\right.$ for $60 \mathrm{sec}$, $59^{\circ} \mathrm{C}$ for $60 \mathrm{sec}, 72^{\circ} \mathrm{C}$ for $\left.60 \mathrm{sec}\right)$; HIC-1: 45 cycles $\left(94^{\circ} \mathrm{C}\right.$ for $45 \mathrm{sec}, 56^{\circ} \mathrm{C}$ for $45 \mathrm{sec}, 72^{\circ} \mathrm{C}$ for $45 \mathrm{sec}$ ); CAGE-1: 45 cycles $\left(94^{\circ} \mathrm{C}\right.$ for $30 \mathrm{sec}, 57^{\circ} \mathrm{C}$ for $30 \mathrm{sec}, 72^{\circ} \mathrm{C}$ for $\left.60 \mathrm{sec}\right)$. Each of the cycling protocols was completed with a final extension step at $72^{\circ} \mathrm{C}$ for $7 \mathrm{~min}$. Following amplification, the PCR fragments were separated on a $3 \%$ agarose gel stained with ethidium bromide ( $5 \mu 1 / 40 \mathrm{ml}$ agarose). Examples of the methylated promoter sequences are shown in Fig. 1.

Immunohistochemistry. For immunohistochemical examination of the protein expression of both the 14-3-3 $\sigma$ and SYK-genes, sections of $2 \mu \mathrm{m}$ thickness were prepared from the archival formalin-fixed and paraffin-embedded samples, mounted on silane-coated slides, dewaxed in xylene, rehydrated in graded ethanol and washed with distilled water. The sections were then incubated in citrate buffer $(\mathrm{pH} 6)$ and subjected to hot water vapor in a chamber for $45 \mathrm{~min}$ at a temperature of approximately $90^{\circ} \mathrm{C}$. Thereafter, the sections were cooled down at room temperature for $20 \mathrm{~min}$ and rinsed in distilled water for $5 \mathrm{~min}$. The specimens were then treated with nonimmune bovine albumin serum (2\%) for $10 \mathrm{~min}$. The primary antibodies: 14-3-3 $\sigma$ mouse monoclonal $\mathrm{IgG1}$, clone 1.N.6, (Abcam Ltd., Cambridge, UK); SYK mouse monoclonal IgG2a, clone D410.1, (Biomeda Corporation, Foster City, CA, USA) were applied at dilutions of 1:50 (14-3-3 o) and 1:100 (SYK) for $30 \mathrm{~min}$ at room temperature. Following washing with Tris-buffered saline (TBS, $\mathrm{pH} 7.4,0.05 \mathrm{M}$ ), the sections were incubated with the biotinylated secondary antibody (ChemMate ${ }^{\mathrm{TM}}$ link detection kit alkaline phosphatase, code no. K 5005, Dako Diagnostika, Hamburg, Germany) for $20 \mathrm{~min}$. After washing with TBS, the specimens were treated with streptavidine alkaline phosphatase (ChemMate detection kit, code no. K 5005, Dako Diagnostika) for $20 \mathrm{~min}$. Following rinsing in TBS, 'fast red' was applied as chromogen (ChemMate detection kit alkaline phosphatase, code no. K 5005, Dako Diagnostika) to visualise the sites of immunoprecipitations. The samples were 
Table IV. Methylation at the promoter region of the genes analysed in undifferentiated small cell carcinomas of the urinary bladder (+ promoter methylation present, - promoter methylation absent).

\begin{tabular}{lccccccc}
\hline \multirow{2}{*}{ No. of case } & \multicolumn{7}{c}{ Methylation status } \\
\cline { 2 - 7 } 1 & $14-3-3 \sigma$ & SYK & CAGE-1 & PTEN & COX-2 & RUNX-3 & HIC-1 \\
\hline 2 & + & + & + & - & - & - & - \\
3 & - & - & - & - & - & - & - \\
4 & - & - & - & - & - & - & - \\
5 & - & - & - & - & - & - & - \\
6 & - & - & - & - & - & - & - \\
7 & - & - & - & - & - & - & - \\
8 & - & - & - & - & - & - & - \\
9 & + & + & + & - & - & - & - \\
10 & - & - & - & - & - & - & - \\
11 & + & - & + & - & - & - & - \\
12 & - & - & - & - & - & - & - \\
\hline Incidence & $12 / 3$ & $12 / 3$ & $12 / 3$ & $12 / 0$ & $12 / 0$ & $12 / 0$ & $12 / 0$ \\
& $(25 \%)$ & $(25 \%)$ & $(25 \%)$ & $(0 \%)$ & $(0 \%)$ & $(0 \%)$ & $(0 \%)$ \\
\hline
\end{tabular}

counterstained with Mayer's haemalaun. Negative control staining was obtained by omission of the primary antibody.

Cytoplasmic immunoreactivity was semiquantitatively stratified into the following categories: diffuse (100\% of carcinoma cells) weak, moderate and strong positivity, and focal weak, moderate and strong immunostaining. The strong immunoreactivity of 14-3-3 $\sigma$ and SYK observed in all layers of the normal appearing, nonneoplastic urothelium adjacent to the cancer tissues served as a standard for evaluating the intensity of the precipitations in the bladder carcinomas. The staining intensity was graded on the basis of the dominant expression pattern, e.g. a tumor showing a predominantly weak staining, but with single or scattered groups of strongly positive cells, was categorised as weakly positive. The protein expression of the CAGE-1 gene could not be examined, since an antibody applicable to paraffin-embedded tissues is not yet commercially available.

Statistical analysis. For statistical analyses, the Pearson Chisquare test was used to detect significant differences in the frequency of promoter methylation and the pattern of protein expression of the various genes in the different histopathological cancer types. A p-value $<0.05$ was considered to be significant.

\section{Results}

Molecular-genetic findings. Our molecular-genetic investigation analysing the methylation status of a broad panel of genes involved in different signalling pathways yielded a frequent hypermethylation at the promoter regions of the 14-3-3 o, SYK and CAGE-1 genes in urinary bladder carcinomas depending on the histopathological subtype, while hypermethylation of the PTEN, COX-2, RUNX-3 and HIC-1 genes was not detectable.

Promoter methylation of the 14-3-3 o gene. The frequency of DNA hypermethylation of the 14-3-3 $\sigma$ gene observed in the various histopathological types of bladder carcinomas is listed in Tables I-IV. By far the highest rate of methylation at the CpG islands was shown for squamous cell carcinomas (80\%), irrespective of their grade of cellular malignancy. More than half of the high-grade, high-stage TCC were detected to be hypermethylated $(57.1 \%)$, compared to only $28.6 \%$ of the low-grade, low-stage TCC. However, the difference proved not to be statistically significant $(\mathrm{p}=0.13$ ), probably because of the relatively small number of cases. The lowest frequency of promoter methylation was shown for undifferentiated small cell carcinomas $(25 \%)$.

Promoter methylation of the SYK gene. The rate of methylation of the promoter site of the SYK gene (Tables I-IV) was highest in advanced muscle invasive TCC (64.3\%) compared to superficial noninvasive TCC (42.9\%) and particularly to undifferentiated small cell carcinoms (25\%) and squamous cell carcinomas (13.3\%). The frequency of promoter methylation between low-grade, low-stage and high-grade, high-stage TCC lacked statistical significance $(\mathrm{p}=0.26)$, while the rate of hypermethylated TCC including all grades and stages (15 of 28 cases) was found to be significantly different $(p=0.007)$ from that of the squamous cell and undifferentiated small cell cancers (5 of 27 cases). Noteworthy, all high-grade, high-stage TCC, except in one case, showing a hypermethylation of SYK also disclosed a promoter methylation of the 14-3-3 $\sigma$ gene (Table II).

Promoter methylation of the CAGE-1 gene. Hypermethylation of the CAGE-1 gene (Tables I-IV) was present in more than half of low-grade, low-stage and high-grade, 

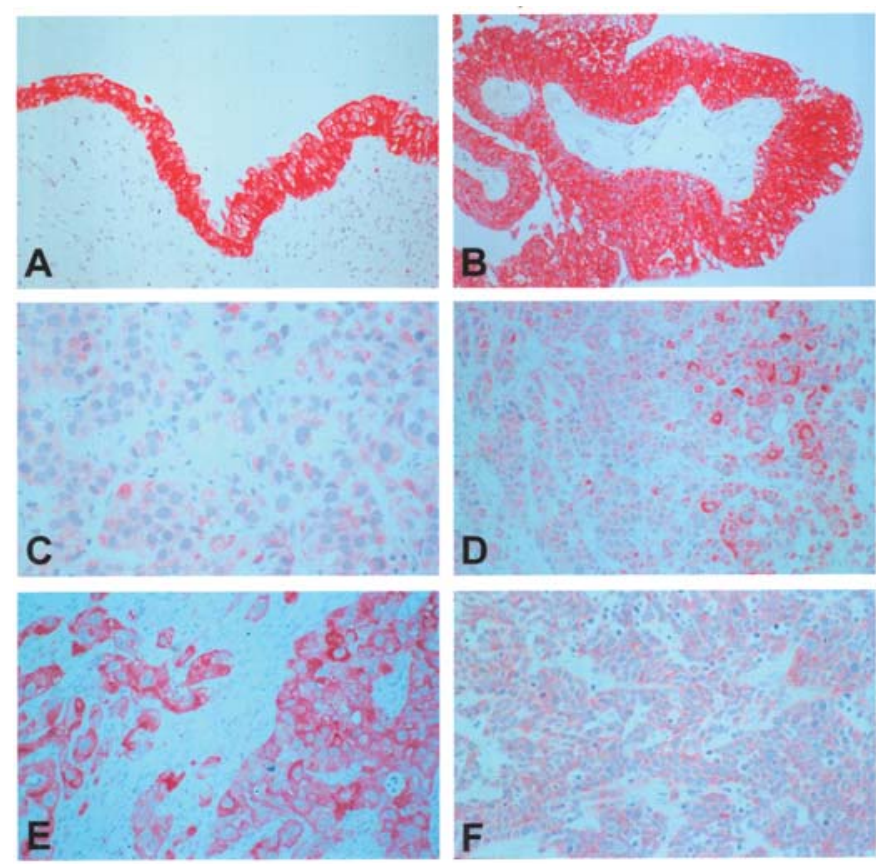

Figure 2. Immunohistochemical expression of 14-3-3 $\sigma$ gene protein (intracytoplasmic deposits, red-coloured) in the normal, nonneoplastic transitional cell epithelium and in the various histopathological phenotypes of bladder carcinomas. (A) Normal urothelium with strong positivity including all cell layers. (B) Low-grade, low-stage papillary transitional cell carcinoma showing a strong immunoreactivity. (C) High-grade, high-stage solid transitional cell carcinoma with a weak expression. (D) High-grade, high-stage transitional cell carcinoma exhibiting a predominantly weak staining and an area with strongly immunopositive tumor cells. (E) Squamous cell carcinoma revealing a strong immunostaining. (F) Undifferentiated small cell carcinoma with weak immunoprecipitations.

high-stage TCC $(64.3 \%)$, and in $53.3 \%$ of squamous cell carcinomas, but only in a quarter of undifferentiated small cell carcinomas. As a relevant finding, all advanced muscle invasive TCC with a promoter methylation of CAGE-1 also showed a hypermethylation of the SYK gene and, with one exception, of the 14-3-3 $\sigma$ gene (Table II).

Promoter methylation of the PTEN, COX-2, RUNX-3 and HIC-1 genes. Hypermethylation of the PTEN, COX-2 and RUNX-3 genes was detected in only single instances, and the HIC-1 gene proved not to be hypermethylated in any of the tumors analysed (Tables I-IV). Since promoter methylation of these genes is evidently not implicated in the epigenetic regulation of bladder carcinogenesis, it will not be discussed in further detail.

Methylation status of the normal bladder mucosa. The six probes of the normal appearing, nonneoplastic mucosa of the urinary bladder all lacked aberrant methylation of the various genes analysed.

Immunohistochemical findings. All layers of the normal appearing, nonneoplastic urothelium adjacent to the carcinomas were characterised by a strong immunohistochemical expression of the 14-3-3 $\sigma$ gene protein (Fig. 2A). The extent and intensity of immunostaining compared with the normal transitional cell epithelium differed considerably between the various histopathological cancer types and within the same tumor (Table V). Superficial, noninvasive low-grade papillary
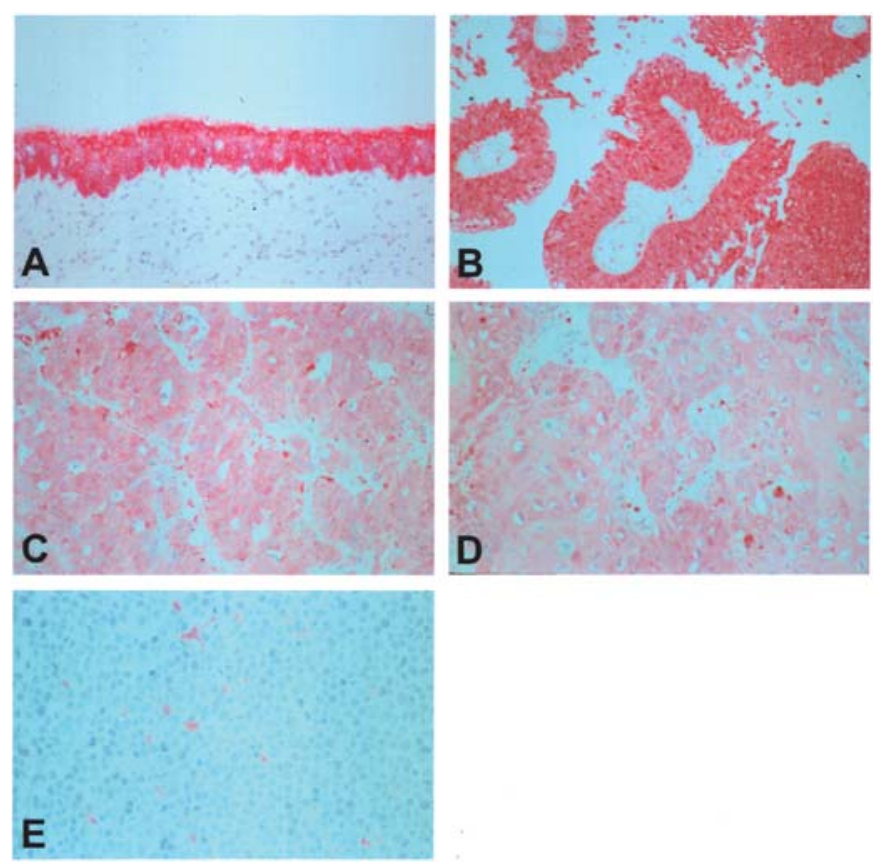

Figure 3. Immunohistochemical expression of SYK gene protein (intracytoplasmic precipitations, red-coloured) in the normal, nonneoplastic urothelium and in the various phenotypical cancer types of the urinary bladder. (A) Normal transitional cell epithelium showing a strong expression in all cell layers. (B) Low-grade, low-stage papillary transitional cell carcinoma with strong immunostaining. (C) High-grade, high-stage solid transitional cell carcinoma and (D) a squamous cell carcinoma disclosing a weak immunoreactivity. (E) Undifferentiated small cell carcinoma lacking expression; interspersed stromal cells with strong deposits.

TCC revealed more frequently a homogeneous moderate and strong diffuse positivity ( $85.7 \%$; Fig. $2 \mathrm{~B})$ than muscle invasive high-grade solid TCC (57.1\%; Fig. 2C), but the difference was statistically not significant $(\mathrm{p}=0.09)$. Some of the high-grade, high-stage TCC with a weak or moderate diffuse or focal expression displayed scattered single or groups of tumor cells with strong deposits (Fig. 2D). All squamous cell carcinomas showed a diffuse strong expression (Fig. 2E). None of the undifferentiated small cell carcinomas exhibited a moderate or strong homogeneous immunostaining and $16.7 \%$ of them were observed to be immunonegative (Fig. 2F). By contrast, none of the TCC and squamous cell carcinomas disclosed a loss of expression.

The protein product of the SYK gene was strongly expressed in all cell layers of the normal, nonneoplastic urothelium neighbouring the cancer tissue (Fig. 3A). The immunohistochemical results obtained for the carcinomas are compiled in Table VI. As with the protein expression of the 14-3-3 $\sigma$ gene, the expression pattern of SYK varied markedly between the different phenotypical cancer types and within the same tumor. Most low-grade, low-stage TCC (Fig. 3B) showed a diffuse immunoreactivity with a moderate or strong staining intensity (78.6\%) and none of them lacked an expression. By constrast, only $14.3 \%$ of the high-grade, highstage TCC (Fig. 3C) disclosed a homogeneous moderate or strong positivity and even $50 \%$ were completely immunonegative. The difference between the expression patterns of superficial and advanced TCC proved to be statistically highly significant $(\mathrm{p}=0.0006)$. Of the squamous cell carcinomas 
Table V. Immunohistochemical protein expression of the 14-3-3 $\sigma$ gene in TCC and nonurothelial carcinomas of the urinary bladder.

\begin{tabular}{|c|c|c|c|c|c|c|c|c|c|c|}
\hline \multirow{3}{*}{$\begin{array}{l}\text { Type of } \\
\text { carcinoma }\end{array}$} & \multirow{3}{*}{$\begin{array}{l}\text { Total no. } \\
\text { of cases }\end{array}$} & \multicolumn{7}{|c|}{ Pattern and intensity of immunoreactivity } & \multirow{3}{*}{$\begin{array}{l}\text { Incidence of } \\
\text { cases with diffuse, } \\
\text { moderate and } \\
\text { strong expression }\end{array}$} & \multirow{3}{*}{$\begin{array}{l}\text { Incidence of } \\
\text { cases with } \\
\text { total loss of } \\
\text { expression }\end{array}$} \\
\hline & & \multirow[t]{2}{*}{ No staining } & \multicolumn{3}{|c|}{ Diffuse immunostaining } & \multicolumn{3}{|c|}{ Focal immunostaining } & & \\
\hline & & & Weak & Moderate & Strong & Weak & Moderate & Strong & & \\
\hline $\begin{array}{l}\text { Low-grade, } \\
\text { low-stage TCC }\end{array}$ & 14 & - & - & 5 & 7 & - & 1 & 1 & $85.7 \%$ & $0 \%$ \\
\hline $\begin{array}{l}\text { High-grade, } \\
\text { high-stage TCC }\end{array}$ & 14 & - & 2 & 3 & 5 & 1 & 1 & 2 & $57.1 \%$ & $0 \%$ \\
\hline $\begin{array}{l}\text { Squamous } \\
\text { cell carcinomas }\end{array}$ & 15 & - & - & - & 15 & - & - & - & $100 \%$ & $0 \%$ \\
\hline $\begin{array}{l}\text { Undifferentiated } \\
\text { small cell } \\
\text { carcinomas }\end{array}$ & 12 & 2 & 1 & - & - & 5 & 1 & 3 & $0 \%$ & $16.7 \%$ \\
\hline
\end{tabular}

Table VI. Immunohistochemical protein expression of the SYK gene in TCC and nonurothelial carcinomas of the urinary bladder.

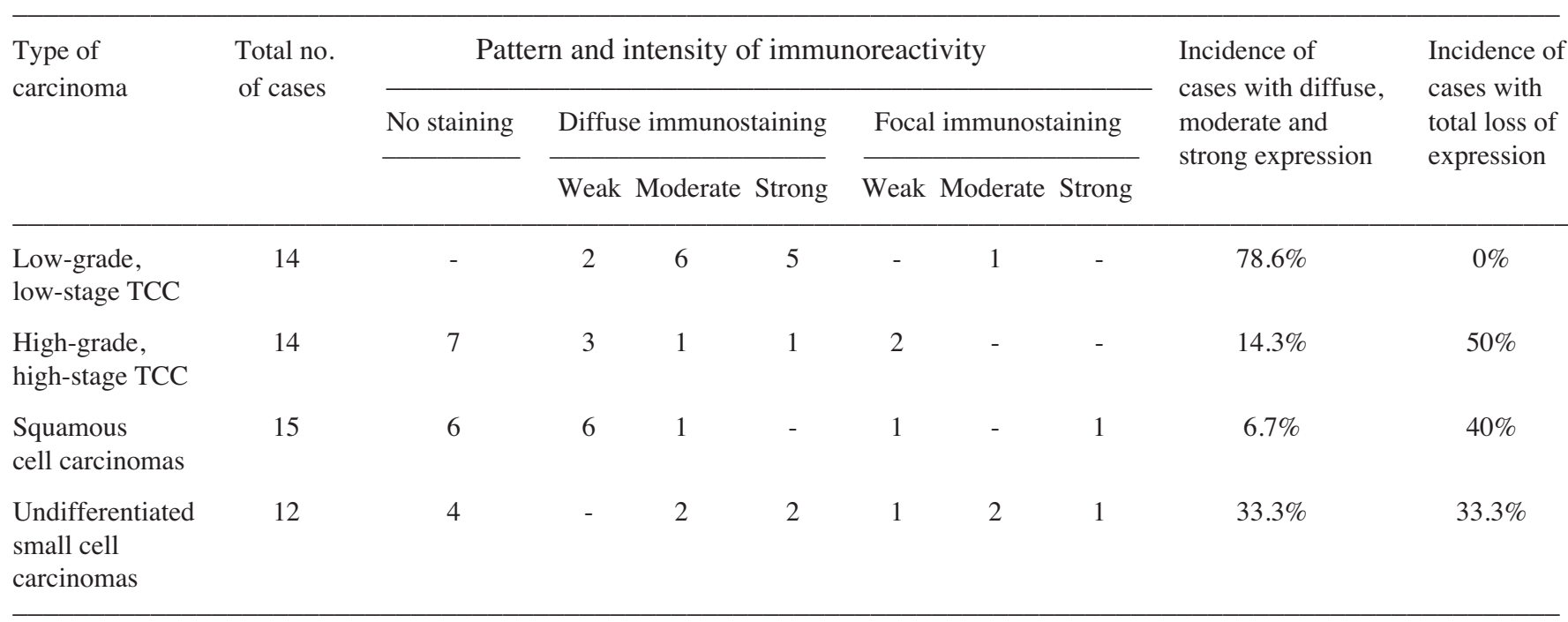

(Fig. 3D) $40 \%$ were observed to be immunonegative and only a single case revealed a homogeneous moderate positivity. One-third of the undifferentiated small cell carcinomas stained negatively throughout (Fig. 3E), while another one-third displayed a diffuse moderate or strong immunoreactivity.

\section{Discussion}

Exploring the significance of epigenetic regulation in modification of urinary bladder carcinogenesis, mediated by methylation of normally unmethylated cytosine in $\mathrm{CpG}$ dinucleotides at 5 ' promoter regions, we analysed a broad panel of genes, among which the 14-3-3 o, SYK and CAGE-1 genes were identified to be target genes. Promoter hypermethylation of these genes was related to tumor cell differentiation, obviously resulting in the formation of the various phenotypical cancer types, and implicated in the progression of TCC to a more malignant potential.

Methylation status and protein expression of the 14-3-3 o gene. The 14-3-3 $\sigma$ gene is activated by the tumor suppressor gene p53 in response to DNA damage, for example following ionizing radiation, and has been documented to be involved in cell cycle regulation by arresting proliferating cells at the transition of the G2-phase to the mitotic phase (G2 check point), allowing repair of altered DNA $(21,22)$. The underlying mechanism consists in the sequestering of the protein kinase cdc2 and the cyclin B1 complex that triggers progression of cells through the $\mathrm{G} 2$-phase and initiates mitosis (23-25). The 14-3-3 $\sigma$ gene produces a protein called stratifin, or HME1, that induces keratinocyte terminal differentiation and is expressed in stratified squamous epithelia $(23,26,27)$. In recent years, the $14-3-3 \sigma$ gene has received 
increasing interest in its possible role during tumorigenesis. Since mutations could not be detected $(14,28,29)$ and loss of heterozygosity proved to be infrequent in human cancers $(14,29)$, studies were conducted to evaluate the significance of epigenetic mechanisms.

In bladder cancers, methylation at the 5' promoter site of the 4-3-3 $\sigma$ gene differed remarkably between the various histopathological types. Muscle invasive high-grade TCC showed a rate of hypermethylation that was twice as high $(57.1 \%)$ as in superficial low-grade TCC (28.6\%), suggesting a crucial role of aberrant methylation of the 14-3-3 $\sigma$ gene in the progression of TCC from a low to a high malignant potential. It might be speculated that methylated low-grade, low-stage TCC are possibly at a higher risk to transform into high-grade, highstage TCC than the unmethylated forms. The highest frequency of promoter methylation was shown for squamous cell carcinomas $(80 \%)$ and the lowest for undifferentiated small cell cancers $(25 \%)$. In light of the above findings, aberrant methylation of the 14-3-3 $\sigma$ gene is obviously involved in the conversion of TCC towards a more aggressive clinical behaviour as well as in phenotypical tumor cell differentiation, resulting in the formation of the different histopathological cancer types.

The crucial role of promoter methylation of the 14-3-3 $\sigma$ gene in tumorigenesis is also evidenced for cancers arising in organs other than the urinary bladder. Invasive ductal carcinomas of the breast were reported to be hypermethylated in between 86 and $96 \%$, respectively, of cases $(14,30)$. Remarkably, $38 \%$ of atypical ductal hyperplasia and $83 \%$ of ductal carcinomas in situ as precursor lesions of breast cancers also proved to be hypermethylated, indicating promoter methylation of the 14-3-3 $\sigma$ gene as an early event in breast cancer development (30). Like breast cancer, hepatocellular $(89 \%)$, gastric $(43 \%)$ and oral $(35 \%)$ carcinomas exhibited frequent aberrant methylation $(28,29,31)$. The role of promoter methylation of the 14-3-3 $\sigma$ gene in modulating phenotypical tumor cell differentiation and transformation as observed in bladder carcinomas is supported by findings in ovarian cancers, clear cell carcinomas showing a significantly higher frequency of methylated 5' $\mathrm{CpG}$ islands (78.6\%) than endometrioid $(20.0 \%)$, serous $(26.3 \%)$ and mucinous $(36.4 \%)$ adenocarcinomas (32).

Immunohistochemically, most TCC including all grades and stages (20 of 28 cases, $71.4 \%$ ) and all squamous cell carcinomas showed a moderate or strong homogeneous immunostaining, while undifferentiated small cell carcinomas were all characterised by a reduced or even lacking expression. In TCC, immunoreactivity was inversely correlated with DNA hypermethylation: frequently hypermethylated (57.1\%) high-grade, high-stage TCC exhibited a considerably lower incidence with a diffuse moderate or strong immunopositivity $(57.1 \%)$ than low-grade, low-stage TCC with a low rate of hypermethylation $(28.6 \%)$ and a homogeneous moderate or strong protein expression in the overwhelming majority of cases $(85.7 \%)$. These findings indicate that the 14-3-3 o gene is partially inactivated by promoter methylation particularly in advanced TCC, but gene silencing with total loss of protein expression was not apparent. However, since the primers used covered only a short sequence of the promoter site, it appears conceivable that other sequences were in fact unmethylated, allowing transcriptional activity, though at a lesser extent. Aberrant methylation was not detected to suppress the expression of stratifin in squamous cell carcinomas which were frequently hypermethylated $(80 \%)$, but displayed unanimously a strong homogeneous immunoreactivity. This may possibly be explained by a particularly high activity and potential of the 14-3-3 $\sigma$ gene for keratinocyte differentiation that cannot be abrogated by promoter methylation. The downregulation of stratifin expression in undifferentiated small cell carcinomas is assumed to be the result of cellular dedifferentiation rather than of DNA hypermethylation which occurred rarely in this cancer type. While the protein expression of the 14-3-3 $\sigma$ gene varied considerably in bladder cancers, aberrant methylation of hepatocellular (31) and ovarian cancers (32) always coincided with a total loss of expression. Hypermethylated breast (14) and gastric cancers (28) were reported to lack RNA expression, indicating promoter methylation as an epigenetic mechanism of transcriptional deregulation and silencing.

Methylation status and protein expression of the SYK gene. The non-receptor type of SYK protein-tyrosine kinase, the locus mapped to chromosome 9 at band q22, contains two Src homology 2 domains in tandem and C-terminal kinase domains with two interdomain regions (reviewed in refs. 33-37). The SYK family of protein-tyrosine kinases was initially documented to be implicated in development and activation of $\mathrm{B}$ and $\mathrm{T}$ lymphocytes by immunoreceptor signalling pathways and to regulate a variety of hematopoietic cell functions (reviewed in refs. 33-37). The SYK gene product also plays a role in several signal transduction pathways in nonhematopoietic cells (reviewed in refs. 33-37), and there is emerging evidence that the gene is involved in tumorigenesis by suppressing cell growth, thus acting as a tumor suppressor (38-41).

Analysing the methylation status of bladder carcinomas, we observed considerable differences in the frequency of DNA hypermethylation of the SYK gene among the various histopathological tumor types. High-grade muscle invasive TCC showed a higher rate $(64.3 \%)$ than low-grade superficial TCC (42.9\%), indicating increased methylation to be correlated with tumor progression. The frequent promoter methylation of low-grade, low-stage TCC suggests aberrant methylation as an early event during development of TCC. The relatively low level of methylated $\mathrm{CpG}$ islands in squamous cell carcinomas $(13.3 \%)$ and undifferentiated small cell carcinomas $(25 \%)$ contradicts an essential role of DNA hypermethylation in the formation of nonurothelial cancers. Involvement of 5' $\mathrm{CpG}$ hypermethylation of the SYK gene in tumorigenesis is supported by data obtained for cancers in organs other than the urinary bladder. Carcinomas of the breast were reported to be hypermethylated in $32 \%$ (39) and $42.5 \%$ (41), and gastric cancers in $34.4 \%$ (15) of the studied cases. In both, breast and gastric carcinomas, promoter methylation was significantly correlated with lymph node metastases.

Immunohistochemically, all bladder carcinomas manifested altered protein expression profiles, differing between the various phenotypical tumor types. An approximately six-fold lower incidence $(14.3 \%)$ of advanced muscle invasive TCC with a diffuse moderate or strong immunoreactivity in 
association with a higher rate of promoter methylation compared to superficial noninvasive TCC (78.6\%) suggests aberrant methylation of the SYK gene concomitant with a downregulation of the protein expression to play a fundamental role in mediating progression of TCC towards a poorer prognosis. In favor of this and a tumor suppressor function is the further observation that, unlike low-grade superficial TCC, half of the high-grade advanced TCC were characterised by gene silencing, as evidenced by a total loss of protein expression. Protein underexpression and a low frequency of DNA hypermethylation in squamous cell and undifferentiated small cell carcinomas indicate that suppression of SYK gene activity in these cancer types is caused by signalling pathways other than promoter methylation. The reduced protein expression in high-grade, high-stage TCC, squamous cell and undifferentiated small cell carcinomas is assumed to be related to the development of bladder cancers with a high malignant potential. The importance of a decreased SYK gene activity in the progression of tumorigenesis is supported by the findings that hypermethylated breast $(38,40,41)$ and gastric (15) carcinomas with a lowered mRNA production showed a high incidence of lymph node (15) and distant metastases (40). The downregulation of mRNA expression points to a deregulation of the protein expression at the transcriptional level.

Methylation status of the CAGE-1 gene. The cancer/testis $\mathrm{CT} /$ antigen gene, CAGE-1, is a novel member of a large family of approximately 20 closely related CT genes identified to date, mapped to the $\mathrm{X}$ chromosome. The antigenic epitopes of the CT genes were initially recognised either by cytotoxic $\mathrm{T}$ lymphocytes (42) or detected by autologous antibody screening (43). They encode autoimmunogenic tumorassociated antigens, capable of eliciting a humoral immune response, although to a limited extent (reviewed in ref. 44). The CT genes, among which the MAGE multigene family and the NY-ESO-1 gene are to date the most frequently explored, are aberrantly expressed in a wide variety of human malignant tumors including bladder cancers $(43,45)$, demonstrated by the expression of their mRNA transcripts and protein products. Expression in adult normal tissues is restricted to the testis and in the case of NY-ESO-1 additionally to the ovary (reviewed in ref. 44). The biological function of the CT antigen family and their potential relevance in tumorigenesis is not yet clear.

The CAGE-1 gene was originally discovered by SEREX analysis (serological analysis of recombinant tumor cDNA expression libraries with autologous serum) of sera from patients with gastric cancers (46) and is expressed, like the other CT antigens, in many various malignant tumor types, but not in the normal tissue counterparts, except of the testis $(16,47,48)$. The significance of CAGE-1 in urothelial carcinogenesis has not yet been evaluated. Since mutational alterations of the antigen could not be identified (16) to possibly explain the aberrant expression in cancers, we analysed the methylation status, yielding a high frequency of hypermethylation in TCC independent of the grades and stages (overall rate 64.3\%) and in undifferentiated small cell carcinomas $(53.3 \%)$. The low frequency of aberrant methylation of undifferentiated small cell carcinomas $(25 \%)$ might be the result of antigen loss during the process of cellular dedifferentiation. The only other study dealing with the methylation status of the CAGE-1 antigen documented a hypomethylation at a frequency of $>60 \%$ in breast, gastric, lung and hepatocellular carcinomas and at a lower rate $(<40 \%)$ in prostate, uterine, cervical and laryngeal carcinomas (16). The authors conclude that hypomethylation mediates the transcriptional activity of CAGE-1 in tumors which is normally repressed by promoter methylation in nonneoplastic tissues, leading to gene silencing. The involvement of CT genes in progression of urothelial carcinogenesis is supported by an increasing mRNA expression of the NYESO-1 gene with increasing tumor grades (49) and of the MAGE genes with increasing stages (50) of TCC.

CT antigens might be potential targets for the development of an antigen-specific human cancer vaccine or for monoclonal antibody-based anticancer immunotherapy. However, the fundamental problem in establishing effective immunization strategies is the fact that the expression of the immunogenic proteins proved to be highly variable in the individual tumors, ranging from an infrequent homogeneous to a heterogeneous weak, moderate or strong staining pattern $(45,49,51,52)$. Moreover, seropositivity occurred, with the exception of NYESO-1, only in a minority of cases (reviewed in ref. 45), as has also been demonstrated for patients with bladder cancer (49).

In conclusion, our combined molecular-genetic and immunohistochemical investigation provides evidence that epigenetic gene regulation mediated by promoter methylation is involved in the modification of urinary bladder carcinogenesis. The high rate of DNA hypermethylation of the 14-3-3 $\sigma$ and SYK genes documented in high-grade, high-stage TCC in association with a reduced or even lacking protein expression compared to low-grade, low-stage TCC indicates aberrant methylation to play a prominent role in the conversion of TCC from a low to a high malignant potential. The significance of epigenetic events in the progression of TCC is strongly supported by the observation that muscle invasive high-grade TCC were characterised by a concurrent methylation of the 14-3-3 $\sigma$, SYK and CAGE-1 genes. The different frequencies of promoter methylation determined in the various histopathological cancer types suggest that methylation-mediated alterations of gene functions are implicated in phenotypical tumor cell differentiation and in the development of nonurothelial carcinomas from pre-existing TCC. A correlation between DNA hypermethylation of the 14-3-3 $\sigma$ and SYK genes and the expression of their protein products did not exist in squamous cell and undifferentiated small cell carcinomas. However, the repressed or lacking activity of the SYK gene in both cancer types and of 14-3-3 $\sigma$ in undifferentiated small cell cancers points to a relationship between the altered protein expression patterns and the poor clinical outcome of these nonurothelial cancers. The relevance of the frequent promoter hypermethylation of the CAGE-1 antigen in TCC and squamous cell carcinomas remains to be clarified, particularly with regard to an antibody based anticancer immunotherapy.

\section{Acknowledgement}

The authors wish to thank Carola Werner, Department of Medical Statistics, University of Göttingen, for performing the statistical analyses. 


\section{References}

1. Cordon-Cardo C and Reuter VE: Alterations of tumor suppressor genes in bladder cancer. Semin Diagn Pathol 14: 123-132, 1997.

2. Orntoft $\mathrm{F}$ and Wolf $\mathrm{H}$ : Molecular alterations in bladder cancer. Urol Res 26: 223-233, 1998 .

3. Knowles MA: The genetics of transitional cell carcinoma: progress and potential clinical application. BJU Int 84: 412-427, 1999.

4. Rabbani F and Cordon-Cardo C: Mutation of cell cycle regulators and their impact on superficial bladder cancer. Urol Clin North Am 27: 83-102, 2000.

5. Laird PW and Jaenisch R: The role of DNA methylation in cancer genetics and epigenetics. Annu Rev Gent 30: 441-464, 1996.

6. Baylin SB, Herman JG, Graft JR, Vertino PM and Issa J-P: Alterations in DNA methylation: a fundamental aspect of neoplasia. Adv Cancer Res 72: 141-196, 1998.

7. Ballestar E and Esteller M: The impact of chromatin in human cancer: linking DNA methylation to gene silencing. Carcinogenesis 23: 1103-1109, 2002.

8. Jones PA and Baylin SB: The fundamental role of epigenetic events in cancer. Nat Rev Genet 3: 415-428, 2002.

9. Kunze E: Histogenesis of nonurothelial carcinomas in the human and rat urinary bladder. Exp Toxicol Pathol 50: 341-355, 1998.

10. Kunze E: Formale Pathogenese des Harnblasenkarzinoms. In: Diagnostik und Therapie des Harnblasenkarzinoms. Bichler KH, Wilbert D, Wechsel HW, Strohmaier WL (eds). Einhorn-Presse Verlag, Reinbeck, pp14-42, 1998.

11. Kunze E, Francksen B and Schulz H: Expression of MUC5AC apomucin in transitional cell carcinomas of the urinary bladder and its possible role in the development of mucus-secreting adenocarcinomas. Virchows Arch 439: 609-615, 2001.

12. Kunze E and Francksen B: Histogenesis of nonurothelial carcinomas of the urinary bladder from pre-existent transitional cell carcinomas. A histopathological and immunohistochemical study. Urol Res 30: 66-78, 2002.

13. Kunze E, von Bonin F, Werner C, Wendt M and Schlott T: Transitional cell carcinomas and nonurothelial carcinomas of the urinary bladder differ in the promoter methylation status of the caveolin-1, hDAB2IP and p53 genes, but not in the global methylation of Alu elements. Int J Mol Med 17: 3-13, 2006.

14. Ferguson AT, Evron E, Umbricht CB, Pandita TK, Chan TA, Hermeking H, Marks JR, Lambers AR, Futreal PA, Stampfer MR and Sukumar S: High frequency of hypermethylation at the 14-3-3 sigma locus leads to gene silencing in breast cancer. Proc Natl Acad Sci USA 97: 6049-6054, 2000.

15. Wang S, Ding YB, Chen GY, Xia JG and Wu ZY: Hypermethylation of Syk gene in promoter region associated with oncogenesis and metastasis of gastric carcinoma. World J Gastroenterol 10: 1815-1818, 2004

16. Cho B, Lee H, Jeong SW, Bang YJ, Lee HJ, Hwang KS, Kim HY, Lee YS, Kang GH and Jeong DI: Promoter hypomethylation of a novel cancer/testis antigen gene CAGE is correlated with its aberrant expression and is seen in premalignant stage of gastric carcinoma. Biochem Biophys Res Commun 307: 52-63, 2003.

17. Kang YH, Lee HS and Kim WH: Promoter methylation and silencing of PTEN in gastric carcinoma. Lab Invest 82: 285-291, 2002.

18. Yu J, Leung WK, Lee TL, Tse PC, To KF and Sung JJ: Promoter hypermethylation of cyclooxygenase-2 in gastric carcinoma. Int J Oncol 22: 1025-1031, 2003.

19. Li QL, Ito K, Sakakura C, Fukamachi H, Inoue KI, Chi XZ, Lee KY, Nomura S, Lee CW, Han SB, Kim HM, Kim WJ, Yamamoto H, Yamashita N, Yano T, Ikeda T, Itohara S, Inazawa J, Abe T, Hagiwara A, Yamagishi H, Ooe A, Kaneda A, Sugimura T, Ushijima T, Bae SC and Yoshiaki I: Causal relationship between the loss of RUNX3 expression and gastric cancer. Cell 109: 113-124, 2002.

20. Waha A, Koch A, Hartmann W, Mach H, Schramm J, Sörensen N, Berthold F, Wiestler OD, Pietsch T and Waha A: Analysis of HIC-1 methylation and transcription in human ependymonas. Int J Cancer 110: 542-549, 2004.

21. Hermeking H, Lengauer C, Polyak K, He TC, Zhang L, Thiagalingam S, Kinzler KW and Vogelstein B: 14-3-3 sigma is a p53-regulated inhibitor of G2/M progression. Mol Cell 1: 3-11, 1997.

22. Chan TA, Hermeking H, Lengauer C, Kinzler KW, Vogelstein B: 14-3-3 sigma is required to prevent mitotic catastrophe after DNA damage. Nature 401: 616-620, 1999.
23. Leffers H, Madsen P, Rasmussen HH, Honoré B, Andersen AH, Walbum E, Vandekerckhove J and Celis JE: Molecular cloning and expression of the transformation sensitive epithelium marker stratifin. A member of a protein family that has been involved in the protein kinase $\mathrm{C}$ signalling pathway. $\mathrm{J}$ Mol Biol 231: 982-998, 1993

24. Toyoshima F, Moriguchi T, Wada A, Fukuda M and Nishida E: Nuclear export of cyclin B1 and its possibile role in the DNA damage-induced G2 checkpoint. EMBO J 17: 2728-2735, 1998.

25. Jin P, Hardy S and Morgan DO: Nuclear localization of cyclin B1 controls mitotic entry after DNA damage. J Cell Biol 141: 875-885.

26. Prasad GL, Valverius EM, McDuffie E and Cooper HL: Complementary DNA cloning of a novel epithelial cell marker protein, HME1, that may be down-regulated in neoplastic mammary cells. Cell Growth Differ 3: 507-513, 1992.

27. Dellambra E, Patrone M, Sparatore B, Negri A, Ceciliani F, Bondanza S, Molina F, Cancedda FD and de Luca M: Stratifin, a keratinocyte specific 14-3-3 protein, harbors a pleckstrin homology $(\mathrm{PH})$ domain and enhances protein kinase $\mathrm{C}$ activity. J Cell Sci 108: 3569-3579, 1995.

28. Suzuki H, Itoh F, Toyota M, Kikucki T, Kakiuchi H and Imai K: Inactivation of the 14-3-3 sigma gene is associated with 5' CpG island hypermethylation in human cancers. Cancer Res 60: 4353-4357, 2000

29. Gasco M, Bell AK, Heath V, Sullivan A, Smith P, Hiller L, Yulug I, Numico G, Merlano M, Farrell PJ, Tavassoli M, Gusterson B and Crook T: Epigenetic inactivation of 14-3-3 sigma in oral carcinoma: association with p16INK4a silencing and human papilloma virus negativity. Cancer Res 62: 2072-2076, 2002.

30. Umbricht CB, Evron E, Gabrielson E, Ferguson A, Marks J and Sukumar S: Hypermethylation of 14-3-3 sigma (stratifin) is an early event in breast cancer. Oncogene 20: 3348-3353, 2001.

31. Iwata N, Yamamoto H, Sasaki S, Itoh F, Suzuki H, Kikuchi T, Kaneto H, Iku S, Ozeki I, Karino Y, Satoh T, Toyota J, Satoh M, Endo $\mathrm{T}$ and Imai K: Frequent hypermethylation of $\mathrm{CpG}$ islands and loss of expression of the 14-3-3 sigma gene in human hepatocellular carcinoma. Oncogene 19: 5298-5302, 2000.

32. Kaneuchi M, Sasaki M, Tanaka Y, Shiina H, Verma M, Ebina Y, Nomura E, Yamamoto R, Sakuragi N and Dahiya R: Expression and methylation status of 14-3-3 sigma gene can characterize the different histological features of ovarian cancer. Biochem Biophys Res Commun 316: 1156-1162, 2004.

33. Flück M, Zürcher G, Andres AC and Ziemiecki A: Molecular characterization of the murine SYK protein tyrosine kinase cDNA, transcripts and protein. Biochem Biophys Res Commun 213: 273-281, 1995

34. Deckert M, Tartare-Deckert S, Couture C, Mustelin T and Altman A: Functional and physical interactions of SYK family kinases with the Vav proto-oncogene product. Immunity 5: 591-604, 1996.

35. Chu DH, Morita CT and Weiss A: The SYK family of protein tyrosine kinases in T-cell activation and development. Immunol Rev 165: 167-180, 1998.

36. Yanagi S, Inatome R, Takano $\mathrm{T}$ and Yamamura H: SYK expression and novel function in a wide variety of tissues. Biochem Biophys Res Commun 288: 495-498, 2001.

37. Sada K, Takano T, Yanagi S and Yamamura H: Structure and function of SYK protein-tyrosine kinase. J Biochem 130: 177-186, 2001.

38. Coopman PJP, Do MTH, Barth M, Bowden ET, Hayes AJ, Basyuk E, Blancato JK, Vezza PR, McLeskey SW, Mangeat PH and Mueller SC: The Syk tyrosine kinase suppresses malignant growth of human breast cancer cells. Nature 406: 742-747, 2000.

39. Yuan Y, Mendez R, Sahin A and Dai JL: Hypermethylation leads to silencing of the SYK gene in human breast cancer. Cancer Res 61: 5558-5561, 2001.

40. Toyama T, Iwase H, Yamashita H, Hara Y, Omoto Y, Sugiura H, Zhang Z and Fujii Y: Reduced expression of the Syk gene is correlated with poor prognosis in human cancer. Cancer Lett 189: 97-102, 2003.

41. Ding YB, Wu ZY, Wang S, Zha XM, Wei Z, Liu XA and Fan P: Hypermethylation of syk gene in promoter region is associated with oncogenesis, metastasis of breast carcinoma. Natl Med J China 84: 290-293, 2004.

42. Van der Bruggen P, Traversari C, Chomez P, Lurquin C, de Plaen E, van den Eynde B, Knuth A and Boon T: A gene encoding an antigen recognized by cytolytic $\mathrm{T}$ lymphocytes on a human melanoma. Science 254: 1643-1647, 1991. 
43. Chen YT, Scanlan MJ, Sahin U, Türeci O, Gure AO, Tsang S, Williamson B, Stockert E, Pfreundschuh M and Old LJ: A testicular antigen aberrantly expressed in human cancers detected by autologous antibody screening. Proc Natl Acad Sci USA 94: 1914-1918, 1997.

44. Scanlan MJ, Gure AO, Jungbluth AA, Old LJ and Chen YT: Cancer/testis antigens: an expanding family of targets for cancer immunotherapy. Immunol Rev 188: 22-32, 2002.

45. Jungbluth AA, Chen YT, Stockert E, Busam KJ, Kolb D, Iversen K, Coplan K, Williamson B, Altorki N and Old LJ: Immunohistochemical analysis of NY-ESO-1 antigen expression in normal and malignant human tissues. Int $\mathrm{J}$ Cancer 92: 856-860, 2001

46. Cho B, Lim Y, Lee DY, Park SY, Lee H, Kim WH, Yang H, Bang YJ and Yeoung DI: Identification and characterization of a novel cancer/testis antigen gene CAGE. Biochem Biophys Res Commun 292: 715-726, 2002

47. Park S, Lim Y, Lee D, Cho B, Bang YJ, Sung S, Kim HY, Kim DK, Lee YS, Song YW and Yeoung DI: Identification and characterization of a novel cancer/testis antigen gene CAGE-1. Biochim Biophys Acta 1625: 173-182, 2003.
48. Iwata T, Fujita T, Hirao N, Matsuzaki Y, Okada T, Mochimaru N, Susumu N, Matsumoto E, Sugano K, Yamashita N, Nozawa S and Kawakami Y: Frequent immune response to a cancer/testis antigen, CAGE, in patients with microsatellite instability-positive endometrial cancer. Clin Cancer Res 11: 3949-3957, 2005.

49. Kurashige T, Noguchi Y, Saika T, Ono T, Nagata Y, Jungbluth A, Ritter G, Chen YT, Stockert E, Tsushima T, Kumon H, Old LJ and Nakayama E: NY-ESO-1 expression and immunogenicity associated with transitional cell carcinoma: correlation with tumor grade. Cancer Res 61: 4671-4674, 2001.

50. Patard JJ, Brasseur F, Gil-Diez S, Radvanyi F, Marchand M, Francois P, Abid-AAD A, van Cangh P, Abbou CC and Chopin D: Expression of MAGE genes in transitional cell carcinomas of the urinary bladder. Int J Cancer 64: 60-64, 1995.

51. Landry C, Brasseur F, Spagnoli GC, Marbaix E, Boon T, Couli P and Godelaine D: Monoclonal antibody 57B stains tumor tissues that express gene MAGE-A4. Int J Cancer 86: 835-841, 2000.

52. Resnick MB, Sabo E, Kondratev S, Kerner H, Spagnoli GC and Yakirevich E: Cancer-testis antigen expression in uterine malignancies with an emphasis on carcinosarcomas and papillary serous carcinomas. Int J Cancer 101: 190-195, 2002. 